\title{
Offshoring to Promote the Internationalization of Family
}

\section{Firms}

\begin{abstract}
This paper analyses the impact of sourcing abroad on exporting in the case of Spanish manufacturing firms that are family-owned. Sourcing abroad can be a channel that places the firm in a better position to export, not only because it increases the productivity of the firm, but also because it provides information, new managerial procedures or just the acceptance by the family owners of a more complex strategy. The empirical analysis presents the premium on the probability of being an exporter for those firms that offshore part of their production, and compares this with the results for non-family firms. The results show that there is a significant premium for SMEs on the probability of exporting, but not on the intensity of those exports, and that this occurs at the same levels in family and non-family firms.
\end{abstract}

Keywords: Offshoring; Exporting; Family Firms

\section{Introduction}

In Spain, as in other advanced economies, family firms are an important part of the production system.

For these firms, internationalization has become a strategy that cannot be considered exceptional.

However, research has shown that the family character may introduce some specific elements to the exporting decision ( Gallo and Sveen 1991 ). There is no consensus on whether family firms have a

Corresponding author: e-mail: fmerino@um.es

Received 01 March 2017 - Accepted 09 June 2017

This is an Open Access article distributed under the terms of the Creative Commons Attribution-Non-Commercial-No Derivatives License (http://creativecommons.org/licenses/by-nc-nd/4.0/), which permits non-comercial re-use and distribution, provided the original work is properly cited, and is not altered or transformed in any way. 
higher or a lower tendency to enter foreign markets, since the traditional vision of family firms being more risk averse has recently been challenged (Gómez-Mejía et al. 2007) or the recent meta-analysis in Arregle et al. (2016). Beyond the attitude to risk, we find that the wish to preserve the family character of the firm limits its access to some critical resources for entry to foreign markets. For instance, the possibility of increasing the firm's financial resources through an expansion in the number of shareholders, or of incorporating top managers with the necessary skills or valuable business networks, will be dependent on the strategy of the owners. As is widely known, many firms have adopted sourcing strategies that suppose changes in the location of some parts of their value chain from the home country to foreign locations. Although a terminological discussion exists, this process is commonly known as offshoring, and it has been implemented with different modalities, depending on whether the development of those activities remain in-house of the firm (this is, the firm establishes some premises abroad where those activities will be developed) or contracts out to a third firm (and those activities will be developed and managed by a firm external to the company that will use the output of those activities). Offshoring, or sourcing some of its intermediate inputs abroad, provides a firm with knowledge and expertise in relation to foreign countries, international economic operations, etc. Moreover, it obliges a family firm to establish some kind of internal status that opens it up to the development of further international operations. Then, beyond the advantage of the assumed improvement in productivity, offshoring may be an extra driver for exporting for those firms that source some of their intermediate inputs abroad.

The aim of this paper is to analyse the importance of this driver for family firms, and to compare the position for non-family firms. It must be noted that family firms have an important weight on the Spanish economy (for instance, Faccio and Lang (2002), show that among Western 
European large corporations $44 \%$ of them can be considered family business, that for Spain reaches 55\% of them or the Instituto de Empresa Familiar (2015), which claims that $88 \%$ of Spanish firms are family business supposing 57\% of the Value Added in Spain) as well on some of multinationals that have emerged in the last decades of the $20^{\text {th }}$ century (Guillén and GarcíaCanal 2010). The analysis is based on the relevance of non-physical resources that fuel internationalization (such as tacit or explicit knowledge, the networks in which the firm is inserted, the expertise of its managers, etc). The results may be interesting both for the research area of the internationalization of family firms, since it will highlight a factor that has not been included in most of the empirical research, and for managers of these firms, who can treat offshoring as a strategy not only for sourcing necessary inputs, but also as a learning process that is part of their internationalization strategy. The core idea of the paper is that this extra knowledge that offshoring may provide to the firm can be a catalyser of the proper firm's exports.

This paper is organized as follows. The next section discusses the concept of offshoring, and summarizes the main reasons found in the literature for adopting this strategy. Section 3 establishes the links between offshoring and the internationalization of firms, and looks at why these links could be different for family firms. Section 4 presents the empirical analysis; the strategies of Spanish family firms on offshoring are shown, and an econometric analysis on the link between offshoring and the development of other international activities is discussed. The last section concludes the paper and presents some lines for further research.

\section{Reasons to offshore}

One of the most remarkable features of production processes in the last two decades has been the reconsideration of the value chain. This reconsideration has happened from a double 
perspective. On the one hand, firms have redesigned the set of tasks that they find to be optimally performed in-house. As a consequence, some activities that were previously developed inside the firm, as part of the process of producing the final output, are now developed by third parties, external to the firm. In some way, that change implies to create (or to use) a market for the provision of some of the intermediate inputs (in the widest meaning of this phrase) that are needed by the firm. This process is usually called outsourcing and has encouraged firms to focus on their core activities, where they may exploit their core competences and become more competitive (for the Spanish case, see Galdón-Sanchez et al. 2015). On the other hand, the geographical position of each activity has been re-considered and some activities have found a better accommodation in new places. As a consequence, firms have abandoned their traditional locations for some activities, searching for places with comparative advantages in which to develop them (see for example Jensen and Pedersen 2011, or Merino 2017). The implementation of these strategies by firms creates an important change in their essential identity that has led some scholars to suggest that the proper nature of a firm must be reconsidered (see Contractor et al. 2010).

This double decision generates a set of four possible strategies for the firm. As is known, the economic literature, as well as business terminology, has used the terms offshoring and outsourcing in a non-uniform way, creating some confusion (see Bhagwati et al. 2004 for a discussion). However, as time has passed it seems that some uses of the different terms have become standard. Figure 1 shows the different situations that may be generated by these two strategies, giving the common names that will be used in this paper. 
Figure 1. Typology of offshoring and outsourcing

\begin{tabular}{|c|c|c|c|}
\hline & \multicolumn{2}{|c|}{ Production is: } \\
\hline & & internalised & externalised (outsourcing) \\
\hline \multirow{2}{*}{$\begin{array}{l}\text { Location } \\
\text { of } \\
\text { production }\end{array}$} & $\begin{array}{l}\text { Home } \\
\text { country }\end{array}$ & $\begin{array}{c}\text { Production kept in-house at } \\
\text { home }\end{array}$ & $\begin{array}{l}\text { Production outsourced to third-party } \\
\text { service provider at home. } \\
\text { (Domestic) outsourcing }\end{array}$ \\
\hline & Abroad & $\begin{array}{l}\text { Production by foreign affiliate } \\
\text { Intra-firm (captive) offshoring }\end{array}$ & $\begin{array}{l}\text { Production outsourced to third-party } \\
\text { provider abroad. } \\
\text { Offshoring / international } \\
\text { outsourcing }\end{array}$ \\
\hline
\end{tabular}

Source: UNCTAD 2004.

For each of the two decisions, we find the justification in two sets of reasons with the same rationale: first, the differential costs between the two alternatives and, second, the inherent cost of the two options. The balance between the cost advantage, if any, of sourcing inputs externally or from abroad and the cost implied by the separation (agent/geographical) will determine the optimal strategy.

The decision on internal provision or outsourcing is explained in the framework of Transaction Costs Economics (Williamson 1979, 2008); this focuses on whether the costs of a transaction between two agents, instead of being incorporated in the same firm, compensate for the cost differential of using an external and specialist firm. In relation to the decision on the provision mode, we find that companies specializing in those intermediate tasks have emerged; these companies can exploit the economies of scale, become highly competitive and use the most advanced state-of-the-art processes, making external provision more appealing. Besides, the production of some intermediate inputs has become more sophisticated, making it more difficult for firms not specialized in them to exploit the advantages of new technologies and production processes. In the same way, transaction costs between the user (buyer) and the producer (seller) of the output of those intermediate tasks have reduced because of digitalization, the 
standardization of production processes, and the extension and emergence of markets for those intermediate inputs. For its part, the optimal location of the production process has been affected by the eruption onto the world markets of countries like China or India, which are capable of producing labour-intensive products at lower prices as a consequence of their comparative advantages, and the reduction in transportation costs (not only in terms of moving merchandise, but also in terms of barriers to international trade or the possibility of transferring across borders anything that can be digitalized, which includes many business services). The combined effect of the two types of change has fostered the displacement of phases of the production process from traditional places to new ones. Obviously these changes can be reversed if the cost differentials change, as some papers have shown (see Freytag et al. 2012 or Cabral et al. (2014) for insourcing or Fratocchi et al. (2014) for backshoring).

From this framework it must not be deduced that short-run profit maximization is the only reason for these strategies. In fact, the literature has shown that other reasons, such as the wish to be subject to a legal system that introduces fewer restrictions or the need to be more flexible to be able to respond to fluctuations in demand, underlie offshoring (see Kedia and Mukherjee 2009, for example). On the other hand, from a behavioural perspective (e.g., Musteen 2016) factors such as the personal experience of managers and their attitudes, emotions and cognitive limitations are determinants of the offshoring strategy of a firm. However, those reasons are no more than a long-term "profit" goal. We may therefore conclude that offshoring is a strategy that aims to place the firm in a better situation in terms of profit, flexibility, etc. (see Diaz-Mora and Gandoy (2008) for an analysis in the Spanish traditional manufacturing industries). It will lead to a more productive/efficient situation, although the productivity/efficiency improvements cannot be measured in terms of total factor productivity, profitability or similar 
measures, since they are only revealed in terms of the ability to handle volatile markets by implementing alternative strategies, or just of not reducing overall productivity by incorporating certain tasks into their activity. Besides, some authors have signalled that outsourcing (and this argument can be extended to offshoring) requires the firm to make a better evaluation of intermediate costs, which may help to improve the organizational structure, thus increasing the firm's competitiveness (Antelo and Bru 2010).

\section{Offshoring and exporting}

The most recent economic literature on exporting departs from models such as those of Grossman et al. (2006) and Melitz and Ottaviano (2008), which introduce the variability among firms in the same industry as an explanation for why some firms export while others do not. The rationale for this different observed behaviour among firms in the same industry, according to those models, is based on the different level of productivity of the firms. A large body of empirical literature has analysed the extent to which the observed differences in productivity between exporters and non-exporters is based on the previous situation (self-selection of the most productive firms to be exporters) or on the knowledge acquisition process that is presumed by exporting (learning-by-exporting, where exporting is initiated by a minor characteristic that leads to further productivity differentials). See the survey by Wagner (2007) on this topic.

Following the classical literature on this topic, this paper takes as its point of departure the wellknown fact that offshoring is presumed to give a basis for being more productive (Olsen 2006 shows that the effect differs across industries, Amiti and Wei (2009), attribute around 10\% of labour productivity growth between 1992 and 2000 in the US to the offshoring of services, Schwörer, 2013, finds a positive effect for European firms too, etc.), so that it can be a strategy that promotes exporting. As was stated in the previous section, offshoring is a strategy that 
allows a firm to reach higher productivity levels than it would if it chose the in-house option (because of the assumed lower costs, the possibility of accessing the most modern technologies to develop the intermediate inputs, the exploitation of economies of scale in the firm's production, the viability of certain specific strategies, etc.). Additionally, offshoring provides a margin of manoeuvre for variations in demand, making the firm more solid and allowing it to dedicate fewer resources to that eventuality.

However, the core idea behind the specific analysis of family firms does not rely on the effect of offshoring on productivity, since it would not suggest a difference between family and nonfamily firms. The point of the analysis of offshoring and exports for family firms is based on certain characteristics of these firms. It must be remembered that the topic of whether some of the special features of family firms may affect their internationalization strategies has a long tradition in the literature (Gallo and Sveen (1991) provide a seminal paper in this field and specific analysis for the Spanish case can be seen in papers such as Fernández and Nieto (2005)). For instance, in a recent paper, Boellis et al. (2016), arguing on the basis of international business studies, corporate finance and the relevance of socioemotional wealth for family firms, conclude that, because of the greater risk aversion and lower access to information of family firms, their international strategies will be different from those of other firms. Horgos (2013), on the basis of the models of Antràs and Helpman (2004), concludes that family firms will be less likely to develop FDI strategies, all other things being equal, so that those firms that actually invest abroad will have more resources to develop an international strategy.

It must be noted that, beyond the productivity or cost advantage that may be generated by offshoring, it may constitute a source of additional knowledge for firms. Firms that offshore (both intra-firm offshoring or proper offshoring as described in the strategies presented in 
Figure 1) will face the cost of handling operations in a different country, with other partners, but this knowledge may have externalities on other activities or contracts that may be developed by the firm. When a firm establishes productive premises in another country, it needs to invest in order to get the necessary information and expertise to do this. This includes knowledge on topics such as the legal system and industrial relations, but it will expand to areas such as the host country's culture or some of the characteristics of the customers. Additionally, the existence of production premises means that the firm starts to develop some social capital in the foreign country, on the basis of its relationships with suppliers of raw materials, business services, etc., as well as the networks established by representatives of the firm with business people in the foreign country. Obviously, in the case of pure offshoring (international offshoring), when the firm only contracts for the production in another country, these elements will be somewhat smaller or non-existent.

Furthermore, offshoring impels the firm to learn how to develop certain international activities (contracts, asset management in different currencies, staff with foreign language and international business skills, importing and dealing with customs, etc.). Then, although the offshoring decision requires some previous knowledge and expertise of international markets, continuing with this strategy will increase the firm's experience abroad and its knowledge of the world beyond its domestic boundaries.

We therefore find that the effect of offshoring on exports is not just the increase in productivity that may be presumed as the result of exploiting lower costs or a less constrained legal/institutional situation, or the additional flexibility it introduces, but includes the knowledge and experience of being in foreign markets. This expertise is especially valuable in relation to a firm's willingness to develop further international activities, since it is not always 
easy to acquire and incorporate such expertise in the firm's structure. Different authors have shown that offshoring is a factor that, for all these reasons, effectively promotes firms' exports (e.g., Coucke and Sleuwaegen (2008) for Belgian manufacturing firms; Bakhtiari (2015) for Australian firms; Bertrand (2011) for French firms; DiGregorio et al. (2009) for US firms, etc.). As was stated in the introduction, the aim of this paper is to find particular insights into the offshoring-exporting relationship in the case of family firms. The family character of a firm is not limited to the fact that an important percentage of its shares are in the hands of a group of individuals who are linked by family ties. As is well known, the definition of family firm has been a topic under discussion in the specialist literature (see Astrachan et al. (2002) for details) and no undisputed consensus has yet been achieved. The purpose of this paper is not to present a new definition of family firms, nor to discuss the adequacy of the existing definitions. The paper therefore takes as its point of departure the fact, shared by most of the existing definitions, that family firms are characterized by some of the features of the owning family being transferred to the firm, and by the firm's decisions demonstrating the wish that the control held by the family will be passed on, to some extent, to future generations. These characteristics constrain the firm's access to the valuable resources needed to develop an internationalization strategy. Hiring managers with the required knowledge may conflict with the family's wish to control the firm. Access to financial resources to develop an internationalization strategy may be in conflict with the reluctance to dilute the participation of the current owners and/or increase the financial leverage. The social capital of the family that is transmitted to the firm is usually linked to the country of origin, and the development of the firm in other countries is constrained by the ties that may be established by the family. We therefore find that there are limits to the possibility of accessing foreign markets, such as access to knowledge, both explicit and implicit, 
constraints on the expansion of business networks, and the transmission of some of the features of the owning family to the firm. It must be remembered that different studies have shown that family-owned firms and non-family firms present a different export activity in different countries and industries (Boellis et al. 2016; Minetti et al. 2015; Sánchez-Bueno and Usero 2014; Segaro et al. 2014; Lin 2012; Fuentes et al. 2007; etc.)

It must be noted that some of the factors that constrain or, at least, impose conditions on the entry of a family firm into foreign markets could be modified for those firms that are offshoring (captive offshoring). Since their sourcing strategy has obliged them to acquire a certain knowledge and expertise in international operations, they will be endowed with some knowledge when considering export decisions. Besides, developing an offshoring strategy will increase factors such as trust in external relationships and international social and business relationships, as well as building agreements and reinforcing trust among family members in operations in different countries. All these elements may promote the firm's exports, so we could expect that offshoring would be an additional driving force for exporting for family firms.

\section{Empirical analysis}

\section{The database}

To analyse the effect of offshoring on exports by family firms, the Encuesta Sobre Estrategia Empresariales (ESEE) was selected for the years 2007-2013. The ESEE is run by the Spanish Ministry of Industry and is an annual survey of a representative sample of Spanish manufacturing firms with more than ten employees. The sample size is around 1500 firms every year, and it has been used many times for empirical analysis, including for topics dealing with offshoring, given its representativeness and quality. 
To explore the family character of a firm, the ESEE specifically addresses whether a family actively participates in the control/management of the firm. Obviously, this information implies that the family character is considered just as a binary question, although there are many other aspects that the literature considers in order to qualify a firm as a family business (Sharma 2004). It has been remarked in the literature that different aspects that shape the family character of a firm may have different influences on its performance (see specifically the case of Sacristán-Navarro et al. 2011, for Spain) that extends to their internationalization path (see, for example, Scholes et al. (2016), for the importance of socioemotional wealth or Merino et al. (2015), for the different dimensions of the F-PEC scale in the internationalization of Spanish family firm, Claver et al. (2009), for the role of long term orientation and the presence of external managers in Spanish family firms too). However, the available data do not allow that approach but only permit us to compare family firms with non-family firms.

As was discussed in section 2, the term offshoring is sometimes used for "captive offshoring" (when the firm invests abroad to establish premises where some of its intermediate inputs will be produced) and sometimes for "international outsourcing" (which refers to the use of contractors located abroad to supply some of the intermediate inputs needed in the production process of the firm). The hypotheses raised in the previous section for why offshoring may have a different influence on internationalization in family firms focus mainly on the "captive offshoring" case, since in this case the knowledge of foreign markets will be greater and there will have been an expansion of social capital into a foreign environment, although one cannot neglect the possibility that some extra push to internationalize may exist in the "international outsourcing" strategy too. The database includes a specific question on whether the firm imports products that are incorporated into its production process from a foreign firm that is either partly 
owned by the (Spanish) firm or integrated into the same group of companies as the (Spanish) firm. For the empirical analysis, those firms that answered this question in the affirmative will be identified as offshorers, because a firm that is producing intermediate inputs abroad on premises (or by a subsidiary/affiliate firm) that belongs to it will be a candidate for obtaining an extra push to internationalize from its foreign production phase. It must be noted that the offshoring mode considered in this paper differs from the one analysed by DiGregorio et al. (2009), who focused on "international outsourcing". Those authors conclude that international outsourcing enhances the international competitiveness of a sample of US SMEs.

Other variables that will be used in the empirical analysis are the firm size, measured by the number of employees at the end of each year, the industry (based on the 2-digit NACE classification), whether the firm exports or not, and the export propensity (export/sales ratio).

\section{The offshoring and exporting strategies of family firms}

The first conclusion about offshoring and exporting can be taken from the data in Table 1. As we can see, offshoring is about three times more common among non-family firms than among family firms. This result holds both for small and medium firms (those with 200 employees or fewer) and large firms (those with more than 200 employees), although among this last group the difference is lower (18.3\% of family firms offshore versus $35.5 \%$ of non-family firms). Meanwhile, the percentage of exporters is similar between family and non-family firms, and the subset of small and medium family firms contains a slightly larger percentage of exporters than the set of non-family firms of the same size. Looking at the export/sales ratio, this shows a smaller value for family firms, which points to a situation in which family firms enter international markets at a similar rate to non-family firms but are not as deeply involved in the international markets as non-family firms. It must be noted that the existing literature has not 
achieved a sound consensus on this matter, either from the theoretical or from the empirical perspective, and the evidence is mixed, although the results of the meta-analysis of Arregle et al. (2016) (with different definitions of family firms) show that the internationalization of these firms does not differ, in statistical terms, from the internationalization of non-family firms.

Table 1. Internationalization and family character

\begin{tabular}{|c|c|c|c|c|}
\hline & \# obs. & Offshore $(\%)$ & Exporters $(\%)$ & $\begin{array}{l}\text { Export/sales } \\
(\%)\end{array}$ \\
\hline Family firms & 5,694 & 4.85 & 66.47 & 28.01 \\
\hline Non-family firms & 7,702 & 14.84 & 65.32 & 30.38 \\
\hline Total & 13,396 & 10.59 & 65.81 & 29.51 \\
\hline Chi2 test of equality & & $345.20 * *$ & 1.93 & \\
\hline
\end{tabular}

Note: ** Rejection of the hypothesis at $99 \%$

Offshoring and exporting: Is it different for family firms?

Using the typology established by the family/non-family character of the firm and whether or not the firm has developed an offshoring strategy, an analysis can be performed of how offshoring affects the exporting activities of family firms and non-family firms. First, four types are established: (1) family firms that are not offshorers, (2) family firms that are offshorers, (3) non-family firms that are not offshorers, and (4) non-family firms that are offshorers. These four non-overlapping classes of firms allow us to construct four dummy variables that will be introduced in the regression models for the probability of being an exporter as well as for the export/sales ratio. These regression models will be estimated for small and medium firms (those with 200 or fewer employees), since size is a clear determinant of exporting behaviour and means that the percentage of exporters in the group of large firms is so high (over $90 \%$ in family as well as in non-family firms) that no effect can be observed. Furthermore, large companies 
usually have access to assets that will substitute for the experience, knowledge, etc. that lies behind the offshoring push for exporting.

In the econometric model, a set of dummy variables to capture the industry of the firm (on a 2digit basis) as well as its size (measured by the number of employees) is included. The results for the logistic regression model for the probability of exporting are presented in Table 2. Note that, to make the interpretation easier, the constant has been excluded, keeping the four dummy variables for the four types of firms of interest.

Table 2. Logit model for the probability of exporting

\begin{tabular}{lc}
\hline Family No offshorers & $0.5971 * *$ \\
& $(4.393)$ \\
Family Offshorers & $3.2220 * *$ \\
& $(3.151)$ \\
Non-family Offshorers & 0.1484 \\
& $(1.087)$ \\
Non-family No offshorers & $3.0928 * *$ \\
& $(8.332)$ \\
Size & $0.0208 * *$ \\
& $(30.748)$ \\
19 Sectorial dummys included & \\
\hline Number of observations & 10,265 \\
Correct predictions & $73.31 \%$ \\
\hline Tests & \\
$\mathrm{H}_{0}:$ Joint significance & $1,769.29 * *$ \\
$\mathrm{H}_{0}:$ FamNoOff=FamOff & $6.7 * *$ \\
$\mathrm{H}_{0}:$ NoFamNoOff=NoFamOff & $71.75 * *$ \\
$\mathrm{H}_{0}:$ (FamOff-FamNoOff $)=($ NoFamOff-NoFamNoOff $)$ & 0.09 \\
\hline$t$-ratios in parentheses &
\end{tabular}

As we can see in these results, for both family firms and non-family firms, the estimated coefficient for offshorers is larger than that for firms that are not offshorers, and the specific test supports the null hypothesis that the difference is statistically significant. In other words, 
those firms that offshore part of their production process show a premium on the probability of being exporters. To give an idea of this premium, the effect on the probability of being an exporter can be computed. The estimated logistic model suggests that, for each firm, the probability of being an exporter is given by:

$$
\operatorname{Pr}(\text { export })=\frac{1}{1+e^{\sum \alpha_{i} \text { Type }(i)+\sum \beta_{i} \text { Dum }-\sec t o r(i)+\sum \delta_{i} \text { Variable }(i)}}
$$

where:

Type(i) $i=1, \ldots 4$ which corresponds to:

Type(1) for family firms that do not offshore

Type(2) for family firms that offshore

Type(3) for non-family firms that do not offshore

Type(4) for non-family firms that offshore

Dum-sector $(i) \mathrm{i}=1, \ldots 20$ are the 20 2-digit industries according to the Spanish national classification (last category omitted in the regression to avoid multicollinearity)

Variable $(i)$, which refers to the other explanatory variables; in the model presented, it represents the firm's size, measured by the number of employees.

Figure 2 shows the estimated probability, for each of the four types of firm, of being an exporter, given the estimated values of the econometric model and the average values of the dummy variables. Given the non-linear character of the logistic regression model, the premium is obviously not constant, and it is displayed for the whole range of the variable that captures the size of the firm. 
Figure 2. Probability of exporting
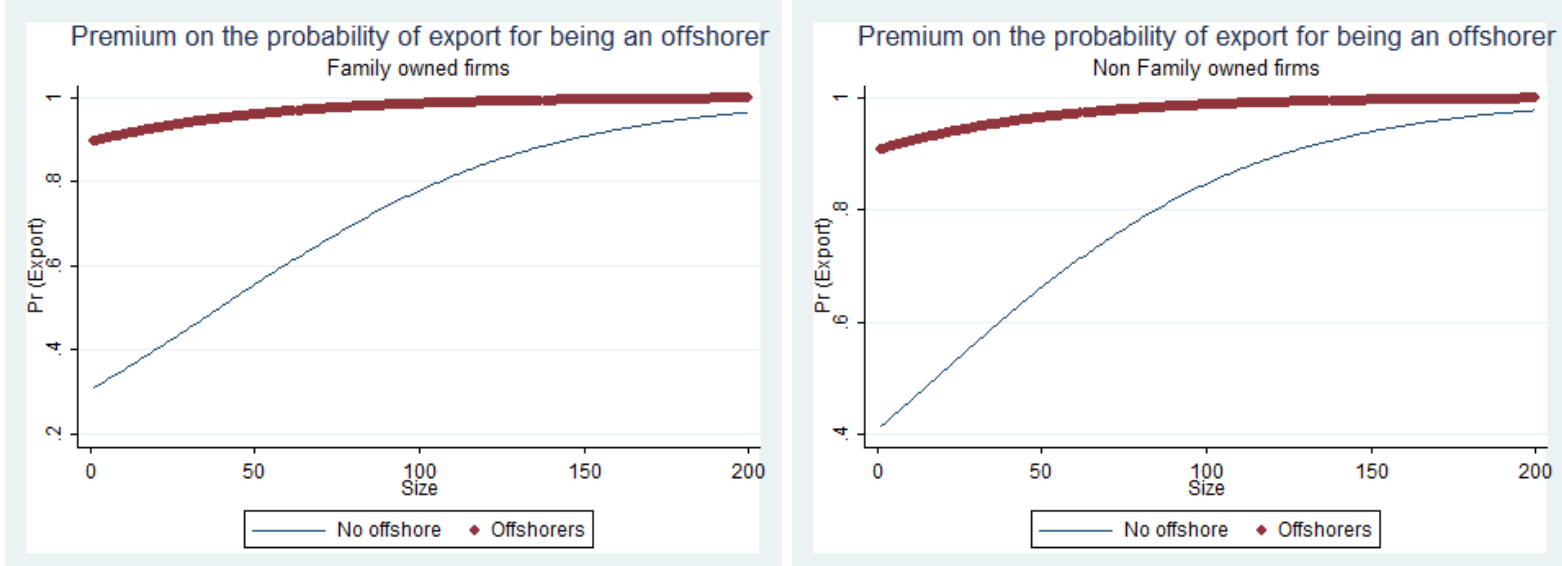

Source: Own elaboration

As can be seen in Figure 2, the probability of being an exporter, everything else being equal, is larger among those firms that offshore than among those that do not, in the case of both family and non-family firms. This difference, the premium on the probability of exporting if the firm has implemented an offshoring strategy, is no more than the result of the estimated coefficients for the two kinds of firms. It can be computed on the basis of the implied probabilities of the estimated logistic model. For family firms, it will be:

Premium $($ FamFirms $)=\operatorname{Pr}($ export $/$ FamFirms \& offhore $)-\operatorname{Pr}($ export $/$ FamFirms \& do not offhore $)$

$$
=\frac{1}{1+e^{\alpha_{2} \text { Type }(2)+\sum \beta_{i} \text { Dum-sector }(i)+\sum \delta_{i} \text { Variable }(i)}}-\frac{1}{1+e^{\alpha_{1} \text { Type }(1) \sum \beta_{i} \text { Dum }- \text { sector }(i)+\sum \delta_{i} \text { Variable }(i)}}
$$

that is, the difference between the probability of exporting for a family firm that offshores (Type(2)) and the probability of exporting for a family firm that does not (Type(1)). In the same way, the premium for non-family firms can be computed as:

Premium $($ NoFamFirms $)=\operatorname{Pr}($ export $/$ NoFamFirms $\&$ offhore $)-\operatorname{Pr}($ export $/$ NoFamFirms \& do not offhore $)$

$$
=\frac{1}{1+e^{\alpha_{4} T \text { ype }(4)+\sum \beta_{i} \text { Dum }- \text { sector }(i)+\sum \delta_{i} \text { Variable }(i)}}-\frac{1}{1+e^{\alpha_{3} T_{\text {Yype }}(3) \sum \beta_{i} \text { Dumn-sector }(i)+\sum \delta_{i} \text { Varable }(i)}}
$$


These premia can be calculated for different values of the explanatory variables. In the results presented in Figure 2, size is revealed as an important factor in establishing the size of these premia. In Figure 3, the values of the premia for family and non-family firms are displayed for an arbitrary mean value of all the other explanatory variables. As Figure 3 shows, the premium on the probability of exporting associated with the fact of offshoring decreases with firm size, which could be due to the fact that, as the firm's size increases, the firm may have other resources that increase its probability of being an exporter. Besides, it must be noted that the logistic model is in accordance with the upper bound of the probability at 1 . In an estimation of a linear probability model, where, contrary to the definition of the dependent variable, such a bound is not included (although this kind of model is used, since it can provide informative results for non-extreme cases), the gradient of the variable size for family firms that offshore is negative but is lower (in absolute value) than for non-family firms.

For the whole range of size, the premium for family firms is larger than that for non-family firms. From the corresponding calculations, we can see that the premium for family firms is about the same as the premium for non-family firms with 25 fewer employees. To validate the hypothesis that this difference is statistically significant, a test over the parameters that adjust these premia is computed (basically $\mathrm{H}_{0}: \alpha_{3-} \alpha_{1}=\alpha_{4}-\alpha_{2}$ ). The result of this test, presented in Table 2, rejects that hypothesis, so we conclude that the premium (on exporting) for offshoring firms is no different between family and non-family firms.

In addition to the effect on the probability of being in international markets, offshoring may have an effect on the intensity of those exports. A similar analysis is presented where the explanatory variable is the export propensity (exports over total sales). 
Figure 3. Premium on the probability of export due to offshoring

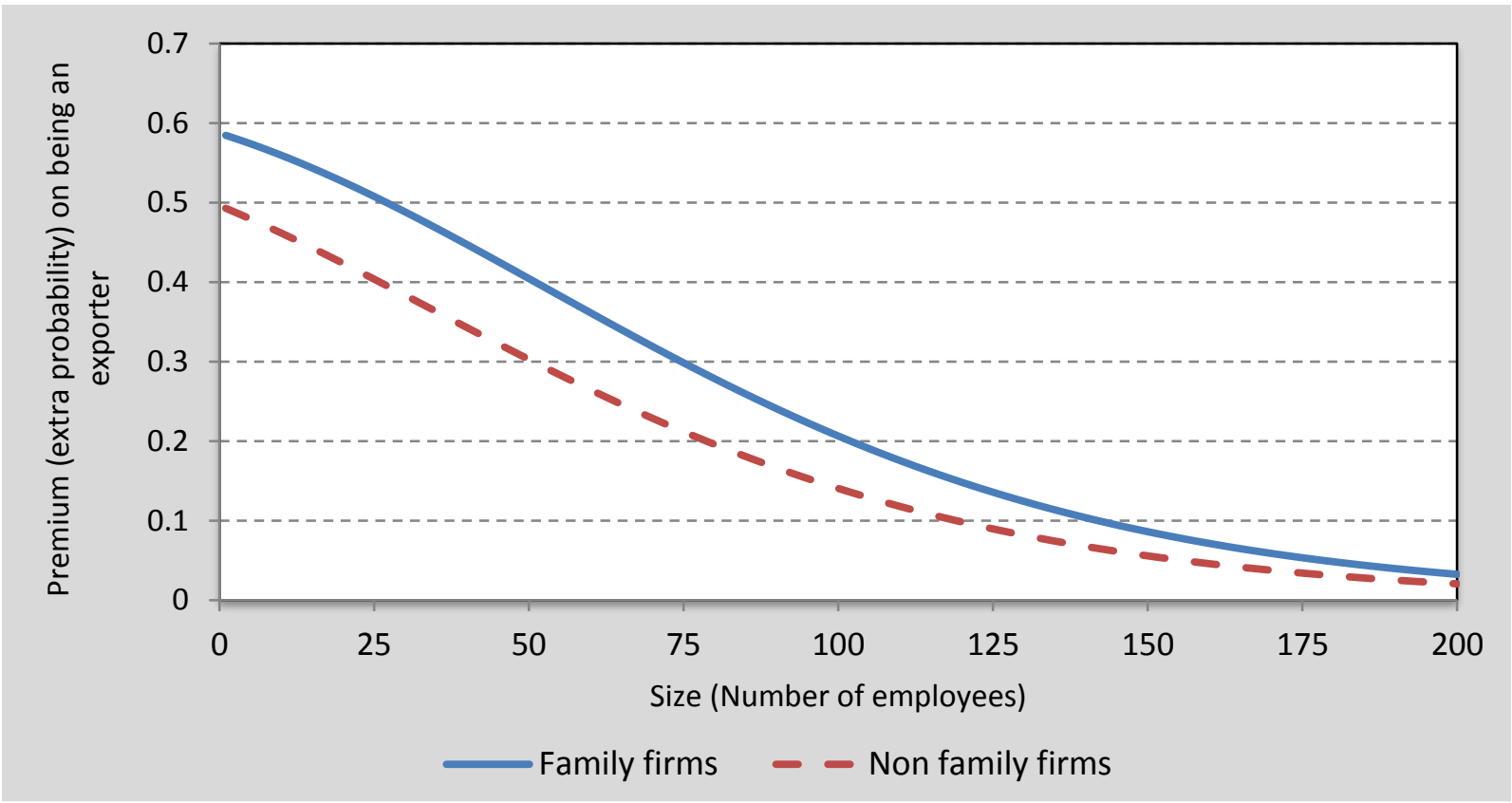

Source: Own elaboration

In addition to the explanatory variables that were included in the binary dependent model, two variables have been included that have been revealed by the existing literature to be significant for the intensity of exports: expenditure on R\&D and advertisement activities. Both elements aim to capture to some degree the differentiation of the output of the firm (in different dimensions), which may foster sales in international markets. Given that the export/sales ratio is a variable that suffers from sample selection (for values with zero exports) the inverse of the Mills ratio is also included as a control variable.

The results of the regression model are presented in Table 3. As we can see, the dummy variables for offshorers are larger than those for firms that do not offshore, in the classes of family and non-family firms. However, the specific tests for the statistical significance of these differences reject the hypothesis that they are different, so the conclusion is that developing an offshoring strategy is not associated in a statistically significant way with a larger export/sales 
ratio, once the higher probability of being an exporter is considered as well as all the other explanatory variables included in the model.

Table 3. Regression model on the export/sales ratio

(OLS, heteroskedasticity robust errors)

\begin{tabular}{|c|c|c|}
\hline Family No offshorers & $\begin{array}{c}38.3094 \\
(13.900)\end{array}$ & $* *$ \\
\hline Family Offshorers & $\begin{array}{l}42.9590 \\
(11.135)\end{array}$ & $* *$ \\
\hline Non-family Offshorers & $\begin{array}{l}39.9673 \\
(13.015)\end{array}$ & $* *$ \\
\hline Non-family No offshorers & $\begin{array}{l}41.2505 \\
(15.193)\end{array}$ & $* *$ \\
\hline Size & $\begin{array}{c}0.0791 \\
(4.674)\end{array}$ & $* *$ \\
\hline R\&D/sales & $\begin{array}{c}0.1934 \\
(1.582)\end{array}$ & \\
\hline Advertisment/Sales & $\begin{array}{l}-0.6839 \\
-(5.490)\end{array}$ & $* *$ \\
\hline Inv. Ratio Mills & $\begin{array}{l}-11.4944 \\
-(3.496)\end{array}$ & $* *$ \\
\hline 19 Sectorial dummys included & & \\
\hline Number of observations & 5,975 & \\
\hline $\mathrm{R}^{2}$ & 0.6035 & \\
\hline Joint significance & 305.29 & $* *$ \\
\hline Tests & & \\
\hline $\mathrm{H}_{0}:$ FamNoOff=FamOff & 2.32 & \\
\hline $\mathrm{H}_{0}:$ NoFamNoOff=NoFamOff & 0.40 & \\
\hline $\mathrm{H}_{0}:$ (FamOff-FamNoOff) $=($ NoFamOff-NoFamNoOff) & 0.97 & \\
\hline
\end{tabular}

$t$-ratios in parentheses

Concerning the other explanatory variables included in the model, we find the usual results: the export propensity increases with the firm's size and technological activities, but this last variable does not reach the usual threshold of statistical significance, which could be due to the low level of technological activities. If the model is run with a dummy variable that reflects whether the firm develops $R \& D$ activities instead of the intensity of $R \& D$ expenditure, the associated coefficient becomes positive and statistically significant. The negative sign for the variable for advertisement intensity is usually attributed to the fact that those expenditures 
suggest that the firm is more concentrated in the domestic market, where it advertising is done or, at least, where the cost of the advertisement is registered in the accounts.

\section{Conclusions}

International Business studies have analysed firms' internationalization from different perspectives. Among the topics covered by these studies, the specific aspects of family firms are one of the topics that intersect with other research areas. Family firms are usually a large part of the economic system, even in advanced economies. The "family" character introduces many aspects that can affect the adoption and success of internationalization strategies. The wish to keep control of the firm within the family group limits the possibilities of obtaining the financial and managerial resources that are required by internationalization strategies. A family firm, to the extent that it is managed by members of the family group that controls its capital, usually inherits some of the features of the family members in its management style; these feature include risk aversion, a greater concern for the firm's reputation, the possibility of exploiting certain social capital but greater difficulties in increasing it, etc.

Implementing internationalization strategies requires not only that the firm's output has certain characteristics, but also that the firm has a network of established relationships so that it can search for potential clients and distributors, obtain information and knowledge about important aspects of foreign markets like customers' tastes and preferences, make links with officials in the public sector, etc. Family firms, which by their nature are more dependent on the family owners, find it more difficult to bring in top managers who can incorporate this knowledge and set up a vast network of contacts abroad, and face internationalization with a different perspective. Moreover, family-owned firms, to the extent that they are more risk averse, will 
want to be more certain of success before becoming involved in a strategy like internationalization that is usually considered to be riskier than growth in the domestic market. For these reasons, the firm may perform other activities that reduce the inherent risks of internationalization in order to promote it. Offshoring (understood in this paper as "captive offshoring", using the UNCTAD 2004 terminology) is one of the strategies that helps the firm to build an international network and become familiar with the characteristics of foreign markets, and that pushes the managers to develop an international framework. It can therefore be a factor that encourages the international activities of the firm. This paper has analysed how developing an offshoring strategy is associated with exporting activities for Spanish manufacturing SMEs that are family-owned. To do this, the premium (that is, the extra probability of being an exporter and having greater export intensity) that offshoring brings for these firms has been estimated.

The results show that those firms that offshore have a significantly higher probability of being exporters. That is, at the same time as these firms supply their production process by manufacturing abroad, they raise their efficiency levels, knowledge, expertise, efficiency, managerial techniques, etc., and this significantly increases their probability of being exporters. It must be noted that non-family firms also benefit from offshoring by being present in international markets in a similar way to family firms. So, the conclusion is that those family firms that are involved in offshoring get the benefit of this strategy to the same extent as nonfamily firms. An interesting result is that, among small and medium manufacturing firms, offshoring is rather less common among family-owned firms than among non-family firms, so it seems that there are a large number of family firms that could exploit the advantage of an offshoring strategy, and this could lead to an even higher percentage of family firms that export. 
In relation to export intensity, the results show that there is no difference between those firms that offshore and those that do not, either for family or for non-family firms. Thus, it seems that offshoring is associated with a higher probability of selling in foreign markets but not with a larger proportion of the total sales taking place there.

From the results of this paper, some topics for future research emerge. First, it seems to be necessary to carry out a more thorough analysis of the features of family firms that may be related to the existence of the observed premium on the probability of exporting for offshorers. The existing literature has shown that the character of family firms includes a series of dimensions (management style, family culture, family socioemotional wealth, etc.), that could be disentangled if the necessary data were available. Another interesting aspect would be to analyse which countries show the linkage between offshoring experience and exporting.

Obviously, the experience of developing international business, gaining expertise in handling international contracts, etc. will be valuable between almost any pair of countries, but between some countries the experience, knowledge, networks etc. will be more valuable and will make a firm more likely to be an exporter.

\section{References}

Amiti, Mary, and Shan-Jin Wey. 2009 "Service Offshoring and Productivity: Evidence from the US." The World Economy 32: 203-220.

Antelo, Manel, and Lluis Bru. 2010 "Outsourcing or restructuring: The dynamic choice." International Journal of Production Economics 123:1-7.

Antràs, Pol, and Elhanan Helpman. 2004. " Global sourcing." Journal of Political Economy 112:552580.

Arregle, Jean-Luc, Patricio Duran, Michael A. Hitt, and Marc van Essen. 2016. "Why Is Family Firms' Internationalization Unique? A Meta-Analysis." Entrepreneurship, Theory and Practice (15 August). doi:10.1111/etap.12246. 
Astrachan, Joseph H., Sabine B. Klein, and Kosmas X Smyrnios. 2002. "The F-PEC Scale of Family Influence: A Proposal for Solving the Family Business Definition Problem." Family Business Review XV:45-58.

Bakhtiari, Sasan. 2015. "Productivity, outsourcing and exit: The case of Australian manufacturing." Small Business Economics 44:427-447.

Bertrand, Olivier. 2011. "What goes around, comes around: Effects of offshore outsourcing on the export performance of firms." Journal of International Business Studies 42:334-344.

Bhagwati, Jagdish, Arvind Panagariya, and T.N. Srinivasan. 2004. "The muddles over outsourcing." Journal of Economic Perspectives 18:93-114.

Boellis, Andrea, Sergio Mariotti, Alessandro Minichilli, and Lucia Piscitello. 2016. "Family involvement and firms' establishment mode choice in foreign markets." Journal of International Business Studies 47:929-950.

Cabral, Sandro, Bertrand Quelin, and Walmir Maia. 2014. "Outsourcing Failure and Reintegration: The Influence of Contractual and External Factors." Long Range Planning 47:365-378.

Claver, Enrique, Laura Rienda, and Diego Quer. 2009. "Family Firms' International Commitment. The Influence of Family-Related Factors." Family Business Review 22:125-135.

Contractor, Farok J., Vikas Kumar, Sumit K. Kundu, and Torben Pedersen. 2010. "Reconceptualizing the Firm in a World of Outsourcing and Offshoring: The Organizational and Geographical Relocation of High-Value Company Functions." Journal of Management Studies 47:1417-1433.

Coucke, Kristien, and Leo Sleuwaegen. 2008. "Offshoring as a survival strategy: evidence from manufacturing firms in Belgium." Journal of International Business Studies 39:1261-1277.

Díaz-Mora, Carmen, and Rosario Gandoy. 2008. "Outsourcing en las industrias tradicionales: Determinantes de la Estrategia." Revista de Estudios Empresariales, Segunda Época 1:41-64.

DiGregorio, Dante, Martina Musteen, and Douglas E. Thomas. 2009. "Offshore outsourcing as a source of international competitiveness for SMEs." Journal of International Business Studies 40:969988.

Faccio, Mara, and Larry H.P. Lang. 2002. "The ultimate ownership of Western European Corporations." Journal of Financial Economics 65:365-395.

Fernández, Zulima, and Maria J. Nieto. 2005. "Internationalization strategy of small and medium sized family businesses: Some influential factors." Family Business Review 18:77-89.

Fratocchi, Luciano, Carmela DiMauro, Paolo Barbieri, Guido Nassimbeni, and Andrea Zanoni. 2014. "When manufacturing moves back: Concepts and questions." Journal of Purchasing \& Supply Management 20:54-59. 
Freytag, Per V., Ann H. Clarke, and Majbritt R. Evald. 2012. "Reconsidering outsourcing solutions." European Management Journal 30:99-110.

Fuentes, Guadalupe, Manuel Carlos Vallejo, and Rubén Fernández. 2007. "Aspectos determinantes en la internacionalización de la empresa familiar." Revista de Estudios Empresariales, Segunda Época 1:38-54.

Galdon-Sanchez, José Enrique, Ricard Gil, and Alberto Bayo-Moriones. 2015. "Outsourcing of peripheral services: Evidence from Spanish manufacturing plant-level data." European Economic Review 78:328-344.

Gallo, Miguel Angel, and Jannicke Sveen. 1991. "Internationalization the family business: Facilitating and restraining factors." Family Business Review 4:181-190.

Gomez-Mejia, Luis R., Katalin Takács Haynes, Manuel Nunez-Nickel, Kathyrn J. L. Jacobson, and José Moyano-Fuentes. 2007. "Socioemotional wealth and business risks in family-controlled firms: Evidence from Spanish olive oil mills." Administrative Science Quarterly 52:106-137.

Grossman, Gene M., Elhanan Helpman, and Adam Szeidl. 2006 "Optimal integration strategies for the multinational firm." Journal of International Economics 70:216-238.

Guillén, Mauro F., and Esteban García-Canal. 2010. The New Multinationals: Spanish Firms in a Global Context. Cambridge and New York: Cambridge University Press.

Horgos, Daniel. 2013. "Global sourcing: a family-firm's perspective." Journal of Small Business \& Entrepreneurship 26:221-240.

Instituto de Empresa Familiar. 2015. La empresa famililar en España. Barcelona: Instituto de la Empresa Familiar.

Jensen, Peter D. Ø., and Torben Pedersen. 2011. "The Economic Geography of Offshoring: The Fit between Activities and Local Context." Journal of Management Studies 48:352-372.

Kedia, Ben L., and Debmalya Mukherjee. 2009. "Understanding offshoring: A research framework based on disintegration, location and externalization advantages." Journal of World Business $44: 250-261$.

Lin, Wen-Ting. 2012. "Family ownership and internationalization processes: Internationalization pace, internationalization scope, and internationalization rhythm." European Management Journal 30:47-56.

Melitz, Marc J., and Gianmarco I.P. Ottaviano. 2008. "Market Size, Trade, and Productivity." Review of Economic Studies 75:295-316.

Merino, Fernando. 2017. "Offshoring, outsourcing and the economic geography of Europe." Papers in Regional Science 96:299-323. 
Merino, Fernando, Joaquín Monreal-Pérez, and Gregorio Sánchez-Marín. 2015. "Family SMEs' Internationalization: Disentangling the Influence of Familiness on Spanish Firms' Export Activity." Journal of Small Business Management 53:1164-1183.

Minetti, Raoul, Pierluigi Murro, and Susan Chun Zhu. 2015. "Family Firms, Corporate Governance and Export." Economica 82:1177-1216.

Musteen, Martina. 2016. "Behavioral factors in offshoring decisions: A qualitative analysis." Journal of Business Research 69:3439-3446.

Olsen, Karsten Bjerring. 2006. "Productivity impacts of offshoring and outsourcing." Working paper 2006/1, OECD STI

Sacristán-Navarro, María, Silvia Gómez-Ansón, and Laura Cabeza-García. 2011. "Family Ownership and Control, the Presence of Other Large Shareholders, and Firm Performance: Further Evidence." Family Business Review 24:71-93.

Sánchez-Bueno, Maria J., and Belen Usero. 2014. "How may the nature of family firms explain the decisions concerning international diversification?" Journal of Business Research 67:1311-1320.

Scholes, Louise, Michael Mustafa, and Stephen Chen. 2016. "Internationalization of Family Firms: The Influence of Family from a Socioemotional Perspective." Thunderbird International Business Review 58:131-146.

Schwörer, Tillman. 2013. "Offshoring, domestic outsourcing and productivity: evidence for a number of European countries." Review of the World Economy 149:131-149.

Segaro, Ethiopia, Jorma Larimo, and Marian V. Jones. 2014. "Internationalisation of family small and medium sized enterprises: The role of stewardship orientation, family commitment culture and top management team." International Business Review 23:381-395.

Sharma, Pramodita. 2004. "An Overview of the Field of Family Business Studies: Current Status and Directions for the Future." Family Business Review 17:1-36.

UNCTAD. 2004. World Investment Report. New York and Geneva: United Nations.

Wagner, Joachim. 2007. "Exports and Productivity: A Survey of the Evidence from Firm-level Data." The World Economy 30:60-82.

Williamson, Oliver E. 1979. "Transaction-Cost Economics: The Governance of Contractual Relations." The Journal of Law \& Economics, 22(2): 233-261.

Williamson, Oliver E. 2008. "Outsourcing: Transaction Cost Economics and Supply Chain Management." Journal of Supply Chain Management 44 (2): 5-16.

This is an Open Access article distributed under the terms of the Creative Commons Attribution-Non-Commercial-No Derivatives License (http://creativecommons.org/licenses/by-nc-nd/4.0/), which permits non-comercial re-use and distribution, provided the original work is properly cited, and is not altered or transformed in any way. 